\title{
Mosquitoes collected on Yap Islands and Ulithi Atoll, Yap State, Federated States of Micronesia (Diptera: Culicidae)
}

\author{
Shinichi Noda ${ }^{1)}$, John Gilmatam ${ }^{2)}$, Kazumasa Ogino ${ }^{3), 4)}$, \\ Takako TomA ${ }^{5)}$ and Ichiro MryaGi ${ }^{6)}$ \\ ${ }^{1)}$ Kagoshima University Research Center for the Pacific Islands, \\ 1-21-24, Korimoto, Kagoshima, 890-8580 Japan \\ ${ }^{2)}$ Department of Health Services, Yap State Government, P.O. Box 148, Colonia, \\ Yap 96943, Federated States of Micronesia \\ 3) Research Laboratory, Sanix Incorporated, 2-1-1, Mukaino, Minami-ku, Fukuoka, 815-0035 Japan \\ 4) Department of Parasitology and Tropical Public Health, School of Medicine, University of \\ Occupational and Environmental Health, 1-1. Iseigaoka, Yahatanishi-ku, 807-8555 Japan \\ ${ }^{5)}$ Laboratory of Medical Zoology, School of Health Sciences, Faculty of Medicine, \\ University of the Ryukyus, 207 Uehara, Nishihara, Okinawa, 903-0215 Japan \\ 6) Laboratory of Mosquito Systematics of Southeast Asia and South Pacific, c/o Ocean Health \\ Corporation, 4-21-11, Iso, Urasoe, Okinawa, 901-2132 Japan
}

(Received: 23 May 2005; Accepted: 8 July 2005)

\begin{abstract}
Mosquito larval surveys were carried out on Yap Islands in October and November 1999. Larvae were collected from 60 natural and artificial habitats. A total of 723 larvae belonging to 10 species including two unidentified species were collected. Among them, Aedes hensilli was the most predominant species collected (70.0\%) followed by Ae. maehleri (13.4\%), Ae. lamelliferus (8.4\%) and Culex quinquefasciatus (4.8\%). The same surveys were also carried out at 56 larval habitats on four inhabited islands of Ulithi Atoll (Mogmog, Falarop, Asor and Fassarai) in October 2001. A total of 658 larvae were collected from 56 habitats on the islands. Two mosquito species, Ae. hensilli (71.9\%) and Cx. quiquefasciatus (28.1\%) were collected from 51 and 9 habitats, respectively. Since Ae aegypti and Ae. albopictus were not collected in the present survey, Ae. hensilli may be implicated as a putative dengue vector in case of an outbreak. Two species, $C x$. annulirostris and Ae. lamelliferus were newly recorded species from Yap Islands.
\end{abstract}

Key words: Aedes hensilli, mosquito fauna, Yap, Ulithi Atoll, Federated States of Micronesia

\section{INTRODUCTION}

It is a well-known fact that major vectors for dengue fever and dengue haemorrghagic fever are Aedes aegypti and Ae. albopictus in urban areas of Southeast Asia and in the Western Pacific Region (WHO, 1995).

Savage et al. (1998) reported a dengue fever/dengue haemorrghagic fever out- break in Yap State between June and July 1995 caused by dengue-type 4 virus. And, entomological investigations implicated the native mosquito species, Ae. hensilli as a previously unrecognized epidemic vector of dengue viruses.

An interdisciplinary research team composed of 30 researchers and students from various faculties of Kagoshima University visited Yap Islands and Ulithi Atoll of Yap State using the training ship of the univer- 
sity. The expedition was aimed at: (1) looking at geological, ecological, bioproductive, hygienic and socio-cultural features of natural and human environments, and (2) in some way contributing to the development of agriculture, fisheries and the actual daily lives of the people of Yap, as well as promoting international exchange between the State of Yap and Japan. This report describes a brief survey of mosquito fauna and breeding sites of mosquitoes in Yap Islands and Ulithi Atoll, Yap State, Federated States of Micronesia.

\section{Materials And Methods}

Yap Islands consists of the four tightly clustered islands of Yap, Tomil-Gagil, Map and Rumung. All but Rumung are connected by bridges. The islands are $829 \mathrm{~km}$ south-west of Guam. Yap Islands has 100 $\mathrm{km}^{2}$ of land. The interior regions are not mountainous, but have gentle rolling hills. The highest point is $174 \mathrm{~m}$. The population is about 7,800. Surveys of larval mosquitoes in nine municipalities of Yap Islands except Rumung were carried out in October and November 1999 (Fig. 1). Ulithi Atoll is $161 \mathrm{~km}$ north-east of Yap
Islands. There are 49 islands with a total land mass of $4.6 \mathrm{~km}^{2}$. They are mere strands of coral and sand rising precariously above the water. Ulithi's inhabited islands (Mogmog, Falarop, Asor and Fassarai) have a total population of just over 1,000. Surveys on the islands were carried out in October 2001 (Fig. 1). Larval collections were made at 60 habitats in Yap Islands and at 56 habitats in Mogmog (14 habitats), Falarop (11 habitats), Asor (14 habitats) and Fassarai (17 habitats). The habitats are composed of coconut shells, tree holes, small water pools, dam (the source of water supply), and artificial containers such as a concrete water tank, canoes as well as discarded tin cans, plastic, metal and ceramic vessels, drums and tires and the collections were made with a pipet and dipper. Collected larvae were preserved in $70 \%$ ethanol, and some larvae were reared to the adult stage, when possible. Identification of the larvae and adults was made by using the keys and descriptions of Bohart (1957) and Bohart and Ingram (1946). And, the classification of the species belonging to the genera Lutzia follows that of Tanaka (2003).

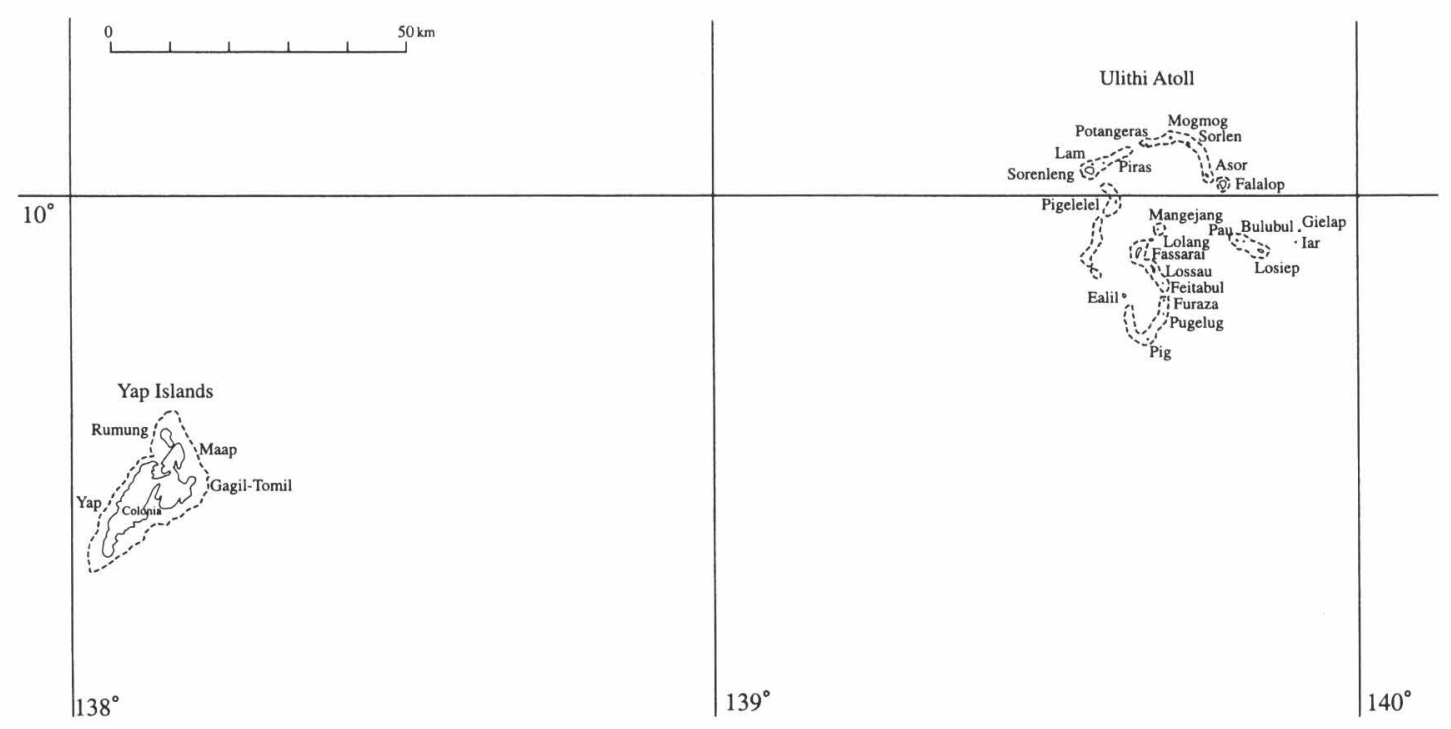

Fig. 1. Map of Yap Islands and Ulithi Atoll. 


\section{RESUlts}

A total of 723 larval mosquitoes belonging to 10 species were collected at 60 various natural and artificial habitats in Yap Islands (Table 1). They are identified as Culex (Culex) annulirostris, Cx. (Cux.) quinquefasciatus, Cx. (Cux.) sitiens, Culex sp., Lutzia (Metalutzia) fuscana $(=C x$. (Lutzia) fuscanus Wiedemann) (Tanaka, 2003), Ae. (Skusea) lamelliferus, Ae. (Stegomyia) hensilli, Ae. (Stg.) maehleri, Aedes sp. and Aedeomyia catasticta. Among them, Ae. hensilli was the most predominant species collected (506 larvae, 70.0\%, 42 habitats) followed by Ae. maehleri (97 larvae, 13.4\%, 15 habitats), Ae. lamelliferus (61 larvae, 8.4\%, 8 habitats) and $C x$. quinquefasciatus (35 larvae, 4.8\%, 2 habitats). The number of the other six species collected Cx. sitiens, Lt. fuscana, Ad. catasticta, Cx. annulirostris, Culex sp. and Aedes sp. was small (24 larvae, 3.3\%, 1 or 2 habitats).

On the four islands of Ulithi Atoll, larval collections were made at 56 habitats. Only two mosquito species, Ae. hensilli and $C x$. quinquefasciatus, were collected from various artificial habitats (Table 1). The larvae of Ae. hensilli (473 larvae, $71.9 \%)$ were collected from 51 habitats

Table 1. Number of mosquitoes and their habitat types collected in Yap Islands and four islands of Ulithi Athol.

\begin{tabular}{|c|c|c|c|c|c|}
\hline & Species & $\begin{array}{c}\text { No. } \\
\text { collected }\end{array}$ & $(\%)$ & $\begin{array}{c}\text { No. of } \\
\text { habitat* }\end{array}$ & Habitat types \\
\hline \multirow[t]{10}{*}{ Yap Islands } & Culex (Culex) annulirostris & 3 & $(0.4)$ & 2 & Coconut shell, small water pool \\
\hline & Culex (Culex) quinquefasciatus & 35 & $(4.8)$ & 2 & Small vessel, tire \\
\hline & Culex (Culex) sitiens & 5 & $(0.7)$ & 1 & Small water pool \\
\hline & Culex sp. & 1 & $(0.1)$ & 1 & Tire \\
\hline & Lutzia (Metalutzia) fuscana & 3 & $(0.4)$ & 2 & Tire \\
\hline & Aedes (Skusea) lamelliferus & 61 & $(8.4)$ & 8 & $\begin{array}{l}\text { Coconut shell, tire, drum, tree } \\
\text { hole, canoe }\end{array}$ \\
\hline & Aedes (Stegomyia) hensilli & 506 & $(70.0)$ & 42 & $\begin{array}{l}\text { Coconut shell, small vessel, tire, } \\
\text { drum, tree hole, canoe }\end{array}$ \\
\hline & Aedes (Stegomyia) maehleri & 97 & $(13.4)$ & 15 & $\begin{array}{l}\text { Coconut shell, tire, tree hole, } \\
\text { canoe }\end{array}$ \\
\hline & Aedes sp. & 5 & $(0.7)$ & 2 & Small water pool, drum \\
\hline & Aedeomyia catasticta & 7 & $(1.0)$ & 2 & Small water pool, dam \\
\hline \multirow[t]{2}{*}{ Mogmog Island } & Culex (Culex) quinquefasciatus & 10 & $(9.3)$ & 2 & $\begin{array}{l}\text { Small vessel, plastic water } \\
\text { barrel }\end{array}$ \\
\hline & Aedes (Stegomyia) hensilli & 98 & $(90.7)$ & 13 & $\begin{array}{l}\text { Coconut shell, small vessel, } \\
\text { plastic water barrel, drum }\end{array}$ \\
\hline \multirow[t]{2}{*}{ Falalop Island } & Culex (Culex) quinquefasciatus & 107 & $(55.2)$ & 4 & $\begin{array}{l}\text { Small vessel, plastic water } \\
\text { barrel, drum }\end{array}$ \\
\hline & Aedes (Stegomyia) hensilli & 87 & $(44.8)$ & 9 & $\begin{array}{l}\text { Coconut shell, small vessel, } \\
\text { plastic water barrel, drum }\end{array}$ \\
\hline \multirow[t]{2}{*}{ Asor Island } & Culex (Culex) quinquefasciatus & 49 & $(33.8)$ & 2 & Small vessel, drum \\
\hline & Aedes (Stegomyia) hensilli & 96 & $(66.2)$ & 13 & $\begin{array}{l}\text { Soconut shell, small vessel, } \\
\text { drum }\end{array}$ \\
\hline \multirow[t]{2}{*}{ Fassarai Island } & Culex (Culex) quinquefasciatus & 19 & $(9.0)$ & 1 & Concrete water tank \\
\hline & Aedes (Stegomyia) hensilli & 192 & $(91.0)$ & 16 & $\begin{array}{l}\text { Coconut shell, small vessel, } \\
\text { plastic water barrel, drum }\end{array}$ \\
\hline
\end{tabular}

* No. of larval mosquito habitats: Yap Islands: 60; Mogmog Island: 14; Falalop Island: 11; Asor Island: 14; Fassarai Island: 17. 
and Cx. quinquefasciatus (185 larvae, $28.1 \%$ ) were collected from 9 habitats.

\section{Discussion}

The climate of Yap State is characterized by constant, warm temperatures, heavy rainfall and high humidity. Surface ground water pools are scarce, especially on Uliti Atoll, and the main mosquito habitats are confined to artificial containers. Mosquito fauna of Yap State has attracted little attention in the past. Much of our present knowledge of the mosquito fauna of these islands is owing to the careful and extensive works of Bohart and Ingram (1946) and Bohart (1957) who recorded 11 species. Recently, Savage et al. (1998) recorded nine species including one additional species Ae. aegypti in Yap State. Infestations of $A e$. albopictus were discovered in Yap in 1995 (CDC information on Ae. albopictus, http://www.cdc.gov/ ncidod/dvbid/arbor/albopic_new.htm). As far as we know, the known mosquito fauna of Yap State consists of 13 species at present.

A single Culex sp. larva was collected from a used tire on Yap Islands. Because of its poor condition, it is difficult to identify it but quite apparently it is a distinct form from the recorded species of Yap Islands, Cx. (Culiciomyia) nigropunctatus and $C x$. (Lophoceraomyia) gossip.

Five Aedes sp. larvae were collected from a small water pool and a drum on Yap Islands. They represent a species probably related to Verrallina pipkini (=Aedes (Verrallina) pipkini Bohart) (Reinert, 1999), but it is difficult to identify them in only the larval stage.

Aedes aegypti is one of the most efficient mosquito vectors for dengue virus. Dengue outbreaks have also been attributed to Ae. albopictus, Ae. polynesiensis, and several species of the Ae. scutellaris complex (WHO, 1997). Ashford et al. (2003) conducted an investigation to assess the extent of the outbreak of dengue fever in Palau on 1995, and determined the risk factor associated with infection including the presence and abundance of the vector species. Potential vectors included the introduced species, Ae. aegypti and $A e$. albopictus, and the native species $A e$. hensilli. Savage et al. (1998) investigated the outbreak of dengue fever in Yap State in 1995. The majority of residents (93100\%) on Yap Islands, Woleai and Eauripik were positive for anti-dengue IgG antibodies, indicating widespread exposure to dengue viruses. And, entomological investigations implicated the native mosquito species, $A e$. hensilli, as vector of dengue viruses. In the present survey, Ae. hensilli was the most abundant and widespread member of Aedes, and $A e$ e aegypti and Ae. albopictus were not collected from Yap Islands and Ulithi Atoll. As stated by Savage et al. (1998), the risk factor analysis in conjunction with data on the distribution and abundance of mosquito species suggests that Ae. hensilli was the primary vector in Yap State.

According to recent $\mathrm{CDC}$ information on Ae. albopictus, which is expanding its distribution in the Pacific region, infestation was discovered in Yap State in 1995. Since this species could not be found in this survey as well as the previous survey by Savage et al. (1998), we believe that $A e$. albopictus is not a primary vector in Yap State and $A$ e. aegypti seems to be still a minor species in Yap State.

Ten mosquito species were collected at various natural and artificial habitats of Yap Islands in this survey. Ae. hensilli was the most abundant mosquito species. In the islands of Ulithi Atoll, Ae. hensilli was also an abundant species. Aedes larvae are container-breeders growing in both clean and organically rich water in both natural and artificial containers. In the present survey, larvae of $A e$. hensilli were collected from different kinds of habitats, such as coconut shells, tin cans, tree holes, old tires, plastic water barrels, drums for water, shells and canoes, often together with Ae. maehleri, Ae. lamelli- 
ferus and Cx. annulirostris. Most of the habitats are artificial containers discarded around human dwellings. Larvae were not collected from leaf axils of taro and banana. It may be notable that $C x$. annulirostris was newly recorded in Yap State. This is one of the vectors of Japanese encephalitis as well as Cx. tritaeniorhynchus and is implicated in an outbreak of Japanese encephalitis which occurred on Saipan, the Commonwealth of the Northern Mariana Islands, in 1999 (Savage et al., 1993).

Environmental management should focus on the destruction, alternation, disposal or recycling of containers that produce the greater number of adult Aedes mosquitoes. These programmes should be conducted concurrently with health education programmes and communications that encourage community participation in the planning, execution and evaluation of container-management programmes (e.g. regular household sanitation or cleanup campaigns) (WHO, 1997).

\section{ACKNOWLEGDMEnTS}

We thank Dr. Y. Higa, National Institute of Infectious Deseases, for providing information and literature on mosquito fauna and dengue in the Pacific Region.

\section{REFERENCES}

Ashford, D. A., Savage, H. M., Hajjeh, R. A., McReady, J., Bartholomew, D. M., Spiegel, R. A., Vorndam, V.,
Clark, G. G. and Gubler, D. G. 2003. Outbreak of dengue fever in Palau, Western Pacific: risk factors for infection. Am. J. Trop. Med. Hyg., 69: 135-140.

Bohart, R. M. 1957. Insect of Micronesia Diptera: Culicidae. Bernice P. Bishop Musium, Insects of Micronesia, 1956 (12): 1-85.

Bohart, R. M. and Ingram, R. L. 1946. Mosquitoes of Okinawa and Islands in the Central Pacific. U.S. Navmed., 1055: 1-110.

Reinert, J. F. 1999. Restoration of Verrallina to generic rank in tribe Aedini (Diptera: Culicidae) and descriptions of the genus and three included subgenera. Contrib. Am. Entomol. Inst. (Gainesville), 31: $1-83$.

Savege, H. M., Frits, C. L., Rutstein, D., Yolwa, A., Vorndam, V. and Gulbler, D. J. 1998. Epidemic of Dengue-4 virus in Yap State, Federated States of Micronesia, and implication of Aedes hensilli as an epidemic vector. Am. J. Trop. Med. Hyg., 59: 519524.

Savage, H. M., Mitchell, C. J., Roppul, M., Castro, L. T., Kepple, R. L. and Flood, S. P. 1993. Mosquito faunal survey of Saipan, Mariana Islands (Diptera: Culicidae): taxonomy and larval ecology. Mosq. Syst., 25: 17-24.

Tanaka, K. 2003. Studies of the pupal mosquitoes of Japan (9). Genus Lutzia, with establishment of two new subgenera, Metalutzia and Insulalutzia (Diptera, Culicidae). Jpn. J. Syst. Entomol., 9: 159169.

WHO 1995. Guidelines for Dengue Surveillance and Mosquito Control. 104 pp., World Health Organization, Geneva.

WHO 1997. Dengue Haemorrhagic Fever: Diagnosis, Treatment, Prevention and Control. 84 pp., World Health Organization, Geneva. 